\title{
Effects of Marketing Strategies on the Performance of Small and Medium-Scale Enterprises in Kogi State
}

\author{
Momoh I. Yalo ${ }^{1} \quad$ Dare Joseph Enimola ${ }^{2} \quad$ Akeem Tunde Nafiu ${ }^{2}$ \\ 1.Department of Marketing, Federal Polytechnic, Idah, Nigeria \\ 2.Department of Business Administration, Kogi State University, Anyigba, Nigeria
}

\begin{abstract}
This study focused on the effects of marketing mix strategies on the performance of SMEs in Kogi State. To achieve the study's objectives, a survey research design was adopted. A purposive sampling was used, and 300 respondents were selected. Findings show that promotion strategy relates negatively and significantly with sales and profitability performance of SMEs in Kogi State. Findings further show that distribution strategy significantly and positively relates with sales performance; while pricing strategy significantly and positively relates with the profitability performance of enterprises in Kogi State. The study concluded that marketing mix strategies have significant effects on sales and profitability performance of SMEs in Kogi State. The study recommends that SME owners should adopt less of promotion strategy to achieve high sales and profitability performance in the business environment of Kogi State, and that more aggressive distribution strategy and pricing strategy should be adopted to sustain sales and the profitability performance of their enterprises in Kogi State.
\end{abstract}

Keywords: Marketing Environment, Marketing Strategies, Sales, Profitability

DOI: $10.7176 / \mathrm{EJBM} / 11-7-03$

Publication date:March $31^{\text {st }} 2019$

\section{Introduction}

Today, some SMEs are struggling to cope with the competition, and others have experienced improved performance in the business environment of Kogi State. Ogbadu (2012) also noted that the tough competition has characterized SMEs more. The successful SMEs have been observed for higher performance (in terms of sales and profitability) in Kogi State. This is perceived the antecedent of effective marketing mix strategies. Mustapha (2017) expressed that marketing strategy is an important tool for any SME to remain in competitive market environment and be stronger. Without the appropriate marketing strategy, an enterprise cannot survive in today's competitive environment nor witness superior performance. The adoptable marketing mix strategies are advertising, promotion, distribution, customer servicing, packaging, sales and distribution strategies. The a-priori expectation is that marketing mix strategies influence increased profitability and sales of SMEs. Mustapha (2017) stressed that ineffective marketing strategy has negative effect on the organization's performance, product quality, customer satisfaction and profitability.

The deficiency noticed from previous studies (Adewale, Adesola and Oyewale, 2013; Kuwu, Gakure and Ngugi, 2014; Mustapha, 2017) is that there is no single marketing strategy theories that explains the performance of SMEs. Even Porter's (1980) theory only identified strategies (cost leadership, differentiation and focus) in relation to large firms. The study of Kuwu et al. (2014) revealed that the development of marketing strategies theories and paradigms concerning SMEs' performance has not reached it momentum yet, despite the studies of the last 10 years. The effect of marketing mix strategies on the performance of SMEs has been a subject of growing interest in the field of strategies management (Kuwu et al., 2014). In the past, many studies on marketing strategies were limited to large enterprises and are carried out in a western context (Olutunia and Obamuyi, 2008). This accounts for few studies on marketing mix strategies to address the issue around performance in the SMEs sector in Kogi State. In the Kogi State context, it is observed that no empirical study has been conducted to investigate the effects of marketing mix strategies on the performance of SMEs in Kogi State. This study therefore explored this gap.

\section{Objectives of the Study}

The main objective of this study is to critically examine the effects of marketing mix strategies on the performance of SMEs in Kogi State. Thus, the specific objectives of the study are to:

i. Ascertain the effects of pricing, product, promotion and distribution strategies on sales performance of SMEs in Kogi State.

ii. Examine the effects of pricing, product, promotion and distribution strategies on the profitability performance of SMEs in Kogi State.

\section{Literature Review}

Goi (2005) defined "marketing strategy as the set of the marketing tools that firms use to pursue their marketing objectives in the target market". This definition appears to be deficient in that it lacks essential keywords or 
terminologies. Adewale et al. (2013) expressed that "the function of marketing strategy is to determine the nature, strength, direction, and interaction between the marketing mix-elements and the environmental factors in a particular situation". Two salient points in this definition is that marketing strategy gives direction, and it is a vibrant explanation of the strength of any marketing SMEs. The determination of this strength may be facilitated through environmental analysis. In almost the same vein, Kuwu et al. (2014) expressed that marketing strategy process involves matching a company's internal resources and capabilities to external environmental opportunities for the company's long-term development. When the SMEs' internal environment/capabilities override the external environmental forces, there is a noticeable strength which can couple up into effective marketing strategy. Ebitu (2015) added that a 'marketing strategy outlines the strategic direction and tactical plans that marketing teams must implement to support the company's overall objectives'. There is an observed mix up in his definition. The reason being that tactical plans only expire within the period of five years. Strategic plan has more than five years life-span, and it must be in alignment with the overall corporate goal.

However, the observed rationale behind the application of strategy to marketing activities trickles down to the pursuit of sales and profitability performance. In another way, Owomoyela, et al. (2013) added that "an organization's marketing strategy is developed to establish, build, defend and maintain its competitive advantage".

Sequel to the above definition and discussion, marketing strategies can be referred to as a road map showing directions on how a long term oriented course of actions must be tailored towards achieving superior performance. It is important to note that marketing strategy is a confidential long term approach which SMEs must consistently use to enhance increasing sales and profitability at the market place. The priority of any marketing strategy is customer's satisfaction. Conventionally, marketing facilitates exchange to increase satisfaction (Ibidunni, 2004). Where the marketing strategy of an SME is effective, it is expected that sales and profitability will be facilitated. As earlier noted, an effective marketing mix strategy must commence with the analysis of the business environment; follow by formulation, implementation and evaluation. The stages of marketing strategies are captured in figure 1. Meanwhile, it is observed that some marketing strategies' failure is attached to problems at the formulation stage. SME owner/manager needs distinctive skill to help them avoid problematic marketing strategy. Kuwu et al. (2014) identified three steps to rescue SMEs from problems at the formulation stage as follows:

i. The SME owner/manager should determine where the enterprise is. This can be done through situation analysis.

ii. The SME owner/manager should determine where the enterprise is going. Kuwu et al. (2014) emphasized on the need for SME owner/manager to 'clearly and equivocally identify the enterprise's mission and long-term objectives'.

iii. The SME owner/manager should outline alternative course of actions from which the best can be chosen after screening. This will establish a pipeline for the enterprise to get to where it intends to be. Kuwu et al. (2014) stressed that SME owner/manager must decide on how to get where it wants to be.

Fig. 1: Conceptual Framework on Marketing Strategies and SMEs' Performance

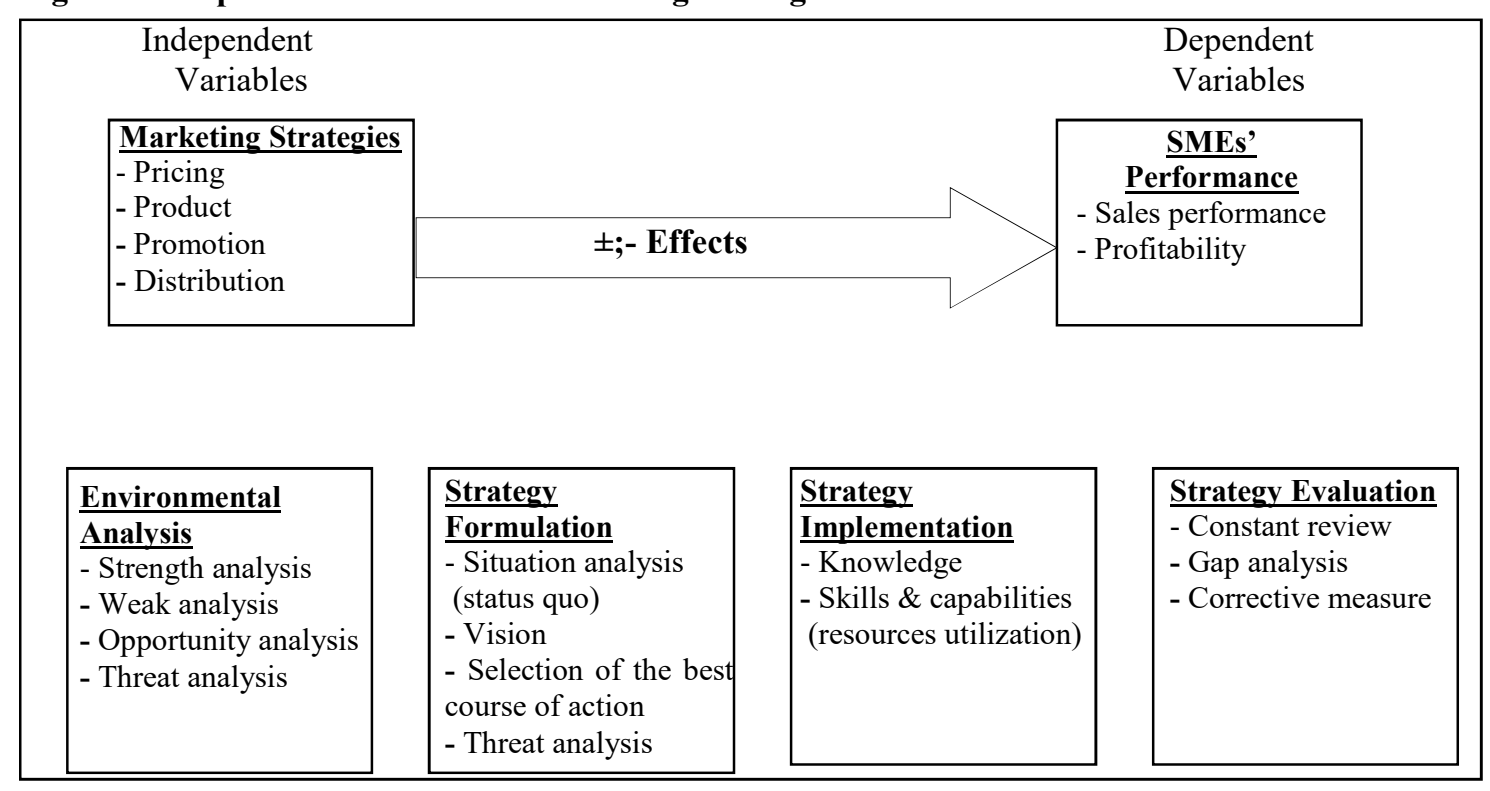

Source: Adopted form Adewale et al., (2013), Kuwu et al., (2014), Ebitu (2016)

However, the implementation of marketing mix strategies is another tasking stage. It requires distinctive 
knowledge of SME owner about the target customers and distinguished prowess and capabilities to judiciously utilize available resources. At the same time, by using available resources, the firm should match its actions and activities with the needs and preferences of customers (Kuwu et al., 2014). The evaluation of marketing mix strategies is observed necessary to ensure that the strategies get the better possible payoff (positive). Almost all enterprises engage in constant evaluation of their marketing strategies to continuously pursue customer's value. The rationale behind this is explained by the game theory. Von Neumann and Morgenstern (1947) expressed that the position of the game theory is that all the enterprise owners are rational, and they struggle individually to create the best customer's value by reviewing their strategies where a loophole is identified or change is observed in the competitive business environment.

\section{Methodology}

Survey research design was adopted for this study. The collection of data was actualized through the use of questionnaires. A five-point Likert scale were used for measurement scaling, ranging from 'strongly agree', 'Agree', 'Neutral', 'Disagree', and 'Strongly Disagree'. The study covers SME owners in Kogi State. The study adopted a purposive sampling based on the fact that secondary data regarding SMEs' operation in totality are absent in the state. The total of 300 respondents was purposively sampled, but 243 questionnaires were retrieved, forming $81 \%$. This is considerably satisfactory for the study's analysis. 136 respondents representing $56 \%$ were male; and 107 respondents representing 44\% were female. About fifty SME clusters were located and surveyed across 15 Local Governments in Kogi State. The dominant SME categories in this study are from the service industry. Other participants belong to various industries such textile, food/beverage, manufacturing and so on. Data were analyzed using percentage and multiple regression model.

\section{Results and Discussion}

The result of this study encompasses both demography and the subject matter.

\section{Table 1: Showing age bracket of respondents}

\begin{tabular}{lcccc}
\hline Responses & Frequency & Percent & Valid Percent & Cumulative Percent \\
\hline Below 20 Years & 47 & 19.3 & 19.3 & 19.3 \\
21-25 Years & 52 & 21.4 & 21.4 & 40.7 \\
26- 30 Years & 82 & 33.7 & 33.7 & 74.5 \\
31-35 Years & 14 & 5.8 & 5.8 & 80.2 \\
36- 40 Years & 15 & 6.2 & 6.2 & 86.4 \\
41- 45 Years & 22 & 9.1 & 9.1 & 95.5 \\
Above 46 Years & 11 & 4.5 & 4.5 & 100.0 \\
Total & 243 & 100.0 & 100.0 & \\
\hline
\end{tabular}

Source: Field Survey, 2018

Table 1 shows that 47 respondents $(19.3 \%)$ were below the age of $20 ; 52$ respondents $(21.4 \%)$ were between the age of 21 to $25 ; 82$ respondents $(33.7 \%)$ were between the age of 26 to $30 ; 14$ respondents $(5.8 \%)$ were between the age of 31 to $35 ; 15$ respondents $(6.2 \%)$ were between the age of 36 to $40 ; 22$ respondents $(9.1 \%)$ were within the age of 41 to 45 ; and 11 respondents $(4.5 \%)$ were 46 years and above. The table systematically reveals that majority of SME owners who adopt marketing mix strategies fall within the age bracket of 26 to 30 years.

Table 2: Showing the level of education of respondents

\begin{tabular}{lcccc}
\hline Responses & Frequency & Percent & Valid Percent & Cumulative Percent \\
\hline Primary & 72 & 29.6 & 29.6 & 29.6 \\
Secondary & 80 & 32.9 & 32.9 & 62.6 \\
College of Education & 48 & 19.8 & 19.8 & 82.3 \\
Polytechnic/University & 43 & 17.7 & 17.7 & 100.0 \\
Total & 243 & 100.0 & 100.0 & \\
\hline
\end{tabular}

Source: Field Survey, 2018

Table 2 shows that 72 respondents $(29.6 \%)$ went through primary school; 80 respondents $(32.9 \%)$ went through secondary school; 48 respondents (19.8\%) went through college of education; and 43 respondents $(17.7 \%)$ went through polytechnic or university. 
Table 3: Showing business experience of respondents

\begin{tabular}{lcccc}
\hline Responses & Frequency & Percent & Valid Percent & Cumulative Percent \\
\hline Below 1 Year & 131 & 53.9 & 53.9 & 53.9 \\
1-2 Years & 46 & 18.9 & 18.9 & 72.8 \\
2-4 Years & 20 & 8.2 & 8.2 & 81.1 \\
4-6 Years & 6 & 2.5 & 2.5 & 83.5 \\
6-10 Years & 4 & 1.6 & 1.6 & 85.2 \\
10-15 Years & 9 & 3.7 & 3.7 & 88.9 \\
Above 15 Years & 27 & 11.1 & 11.1 & 100.0 \\
Total & 243 & 100.0 & 100.0 & \\
\hline
\end{tabular}

Source: Field Survey, 2018

Table 3 shows that 131 respondents $(53.9 \%)$ have the business experience below 1 year; 46 respondents (18.9\%) have the business experience of 1 to 2 year; 20 respondents $(8.2 \%)$ have the business experience of 2 to 4 year; 6 respondents $(2.5 \%)$ have the business experience of 4 to 6 year; 4 respondents $(1.6 \%)$ have the business experience of 6 to 10 year; 9 respondents $(3.7 \%)$ have the business experience of 10 to 15 year; and 27 respondents (11.1\%) have the business experience of 15 years and above.

Table 4a: Multiple Regression Model Summary on marketing mix strategies and sales performance

\begin{tabular}{cccc}
\hline Multiple R & R Square & Adjusted R Square & Apparent Prediction Error \\
\hline $\mathbf{5 6 2}$ & .316 & .292 & .684 \\
\hline
\end{tabular}

Dependent Variable: sales performance

Predictors: pricing, product, promotion and distribution

Table 4b: ANOVA on marketing mix strategies and sales performance

\begin{tabular}{lccccc}
\hline & Sum of Squares & Df & Mean Square & F & Sig. \\
\hline Regression & 76.694 & 8 & 9.587 & 13.489 & .000 \\
Residual & 166.306 & 234 & .711 & & \\
Total & 243.000 & 242 & & & \\
\hline
\end{tabular}

Dependent Variable: sales performance

Predictors: pricing strategy, product strategy, promotion strategy and distribution strategy

Table 4c: Coefficients on marketing mix strategies and sales performance

\begin{tabular}{|c|c|c|c|c|c|}
\hline \multirow[t]{2}{*}{ Predictors } & \multicolumn{2}{|c|}{ Standardized Coefficients } & \multirow[t]{2}{*}{ Df } & \multirow[t]{2}{*}{$\mathbf{F}$} & \multirow[t]{2}{*}{ Sig. } \\
\hline & Beta & Estimate of Std. Error & & & \\
\hline Pricing strategy & .353 & .223 & 2 & 2.498 & .084 \\
\hline Product strategy & .402 & .261 & 2 & 2.370 & .096 \\
\hline Promotion strategy & -.567 & .196 & 2 & 8.347 & .000 \\
\hline Distribution strategy & .378 & .091 & 2 & 17.078 & .000 \\
\hline
\end{tabular}

Dependent Variable: Sales performance

Table 4a shows the $R^{2}$ of 0.316 . This means that $31.6 \%$ of the variation in the sales performance of SMEs is explained by the regression on the optimally transformed predictors (pricing, product, promotion and distribution). The Multiple $R$ of 0.562 shows that the model has a good strength when all predictor variables are combined appropriately.

Table $4 \mathrm{~b}$ shows that the $\mathrm{F}$-value $(\mathrm{F}=13.489 ; \mathrm{P}=0.01)$ is a good one. The ANOVA table speaks well about the model. Since the F-value is significant, it shows that the model does not occur by chance.

Table $4 \mathrm{c}$ shows that only two strategies (promotion and distribution strategies) significantly relates with the sales performance of SMEs in Kogi State. This supports the finding of Mustapha (2017) that promotion and distribution strategies have significant relationship with performance of SMEs. Given the $\beta$-value $=-0.567$ at the $\mathrm{p}$-value $=0.01$, the table $4 \mathrm{c}$ shows that $56.7 \%$ change in the promotion strategy will bring about proportional decrease in the sales performance of SMEs in Kogi State. That is, promotion strategy relates with sales performance of SMEs in Kogi State negatively. This result may occur as a result of the fact that there are unobserved shortfall in the promotion strategies of SME owners in the study area. The implication of this is that more investment in promotion strategy will cost the owner/managers of SMEs, and it will have dwindling effect on their sales performance. Also, given that $\beta=0.378$ at $p$-value $=0.01$ as shown in the table $4 \mathrm{c}, 37.8 \%$ change in the distribution strategy will lead to corresponding change in the sales performance of SMEs in Kogi State. The result shows that distribution strategy positively correlates with sales performance of SMEs in Kogi State. Meanwhile, pricing strategy $(\beta=0.353$; $p$-value $>0.05)$ and product strategy $(\beta=0.402$; $p$-value $>0.05)$ are not significant. Though, the strategies are observed to be having positive relationship with sales performance of SMEs in Kogi State. The finding of this present study refutes the finding of Oyedijo et al. (2012) that pricing strategy and product strategy significantly relate with the performance of SMEs. 
Table 5a: Multiple regression model summary on marketing mix strategies and profitability performance

\begin{tabular}{cccc}
\hline Multiple R & R Square & Adjusted R Square & Apparent Prediction Error \\
\hline $\mathbf{7 1 5}$ & .512 & .493 & .488 \\
\hline
\end{tabular}

Dependent Variable: Profitability performance

Predictors: Pricing, product, promotion and distribution

Table 5b: ANOVA on marketing mix strategies and profitability performance

\begin{tabular}{lccccc}
\hline & Sum of Squares & Df & Mean Square & F & Sig. \\
\hline Regression & 124.396 & 9 & 13.822 & 27.153 & .000 \\
Residual & 118.604 & 233 & .509 & & \\
Total & 243.000 & 242 & & & \\
\hline
\end{tabular}

Dependent Variable: Profitability performance

Predictors: pricing strategy, product strategy, promotion strategy and distribution strategy

Table 5c: Coefficients on marketing mix strategies and profitability performance

\begin{tabular}{lccccc}
\hline & \multicolumn{2}{c}{ Standardized Coefficients } & df & F & Sig. \\
\cline { 2 - 3 } Pricing strategy & Beta & Estimate of Std. Error & & & \\
Product strategy & .761 & .249 & 3 & 9.320 & .000 \\
Promotion strategy & .364 & .318 & 3 & 1.309 & .272 \\
Distribution strategy & -.680 & .196 & 2 & 12.002 & .000 \\
\hline
\end{tabular}

Dependent Variable: Profitability performance

Table 5a shows the $R^{2}$ of 0.512 . This means that $51.2 \%$ of the variation in the profitability performance of SMEs is explained by the regression on the optimally transformed predictors (pricing, product, promotion and distribution). The Multiple $R$ of 0.715 shows that the model has a good strength when all predictor variables are combined appropriately. Table $5 \mathrm{~b}$ shows that the $\mathrm{F}$-value $(\mathrm{F}=27.153 ; \mathrm{P}=0.01)$ is a good one. The ANOVA table speaks well about the model. Since the F-value is significant, it also shows that the model does not occur by chance. Table 5c shows that pricing and promotion strategy significantly relate with profitability performance of SMEs in Kogi State. Given the $\beta$-value $=0.761$ at the $p$-value $=0.01$, pricing strategy also positively relates with the profitability performance of SMEs in Kogi State. It indicates that $76.1 \%$ change in pricing strategy adoption will lead to proportionate change in the profitability performance of SMEs in Kogi State. Interestingly, promotion strategy also negatively relates with the profitability performance of SMEs in Kogi State (given $\beta$-value $=-0.680$ at the $\mathrm{p}$-value $=0.01$ ). The implication of the result is that $68 \%$ change in promotion strategy will bring about the same percentage inverse change in the profitability performance of SMEs in Kogi State. Product strategy $(\beta$-value= 0.364 at the $p$-value $>0.05)$ and distribution strategy $(\beta$-value $=-0.089$ at the $p$-value $>0.05)$ do not significantly relates with the profitability performance of SMEs in Kogi State. This study refutes the finding of Adewale et al. (2013) that product strategy significantly relates with profitability. This present study does not align with the finding of Ebitu (2016) that 'product quality strategy' significantly relates with the profitability of SMEs in Akwa Ibom State. It shows that the business scenario of Kogi State varies from other states across the country.

\section{Conclusion}

It is empirically verified that marketing mix strategies have significantly weak effect on sales performance of SMEs in Kogi State. Results show that pricing, product, promotion and distribution strategies play out individually in relation with sales performance of SMEs in Kogi State. Promotion strategy has significant negative relationship with sales performance of SMEs; and distribution strategy has significant positive relationship with sales performance of SMEs. Pricing and product strategy do not have significant relationship with the sales performance of SMEs in Kogi State.

Profitability performance of SMEs in Kogi State is significantly influenced by marketing mix strategies (pricing, product, promotion and distribution). Based on the empirical findings, pricing and promotion strategies have significant relationship with the profitability performance of SMEs in Kogi State. Interestingly, promotion strategy has significant relationship with the profitability performance of SMEs in Kogi State. This means that the more the SME owners expends resources on promotion strategy the less the profitability becomes. This also implies that promotion strategy is not healthy for SMEs based on their scope.

\section{Recommendations of the Study}

The study recommends that:

i. SME owners should adopt less of promotion strategy to achieve high sales and profitability performance in the business environment of Kogi State.

ii. SME owners should adopt more aggressive distribution strategy to increase their sales performance in Kogi State. 
iii. SME owners should be more committed to their pricing strategy to sustain the profitability performance of enterprises in Kogi State.

\section{REFERENCES}

Aaker, D. (2008). Strategic Market Management. New York. John Willey

Adewale, G., Adesola, M.A. and Oyewale, I. (2013). Impact of Marketing Strategy on Business Performance A Study of Selected Small and Medium Enterprises (SMEs). IOSR Journal of Business and Management (IOSRIBM). 11(4): 59-66. Accessed from http://www.iosrjoumals.org/iosrjbm/papers/Vol11-issue4/101145966.pdf Ameh, AA. (2010). Elements of Marketing. Revised Edition. Abuja: Precious Treasures LTD

Barney, J.B. (1991). Firm Resources and Sustained Competitive Advantage. Journal of Management, 17: 99-120. Barney, Jay B. (1991). Firm Resources and Sustained Competitive Advantage. Journal of Management. 17(1): 310. journals.sagepub.com/doi/abs/10.1177/014920639101700108

Barney, Jay B. and Edward J. Zajac. (1994). Competitive organizational behaviour: Toward an organizationallybased theory of competitive advantage. Strategic Management Journal, 15 (Winter): 5-9.

Dzisi, S. and Ofosu, D. (2014). Marketing Strategies and the Performance of SMEs in Ghana. European Journal of Business and Management, 6(5): 102-111

Ebitu, ET. (2015). Market management and strategy. Calabar: University of Calabar Printing Press.

Ebitu, ET. (2016). Marketing Strategies And The Performance Of Small And Medium Enterprises in Akwa Ibom State, Nigeria. British Journal of Marketing Studies. 4(5): 51-62. Accessed from www.eajournals.org

Goi, C.L. (2005). Marketing Mix: A Review of '4Ps'. In E.T. Ebitu (eds). Market management and strategy. Calabar: University of Calabar Printing Press.

Ibidunni, O.S. (2004) Marketing Management: practical perspective, Lagos, Nigeria: Concept publications.

Kesinro, O.R., Ogunlusi, G. and Adu, C.A. (2016). Entrepreneurial Marketing and SMES Performance. Imperial Journal of Interdisciplinary Research, 2(1): 98-101. Accessed from www.onlinejournal.in

Kotler, P. and Armstrong, G. (2006), Principles of Marketing, 10th Edition, Delhi: Pearson Education, Inc.

Kuwu, EA. and Gakure, R.W. (2014). Effects of Marketing Strategies, 4ps of Marketing Elements and Firm Resources on the Performance of Small and Medium Enterprises in Nigeria. International Journal of Advanced Research in Statistics, Management and Finance. 2(1): 102-117.

Kuwu, E.A., Gakure, R.W. and Ngugi, PK. (2014). Effects Of Marketing Strategies, Marketing Elements (4ps) and Leadership Styles on the Performance of Small And Medium Enterprises In Nigeria. International Policy Brief Series Education \& Science Journal. 4(1): 218-236. www.intemationalpolicybrief.org

Learnmarketing (2015). The marketing mix: product strategies. Available at: http://www.learnmarketing.net/product.htm

Manijeh, H., Bahram, S., Mina, E. and Parastoo, R. (2013). Identification of Innovative Marketing Strategies to Increase the Performance of SMEs in Iran. International Journal of Fundamental Psychology and Social Sciences, 3(2): $26-30$

Martinez-Lorente, A., Dewhurst, F., \& Gallego-Rodriguez, A. (1999). Relating TQM, marketing and business performance: An exploratory study. Accessed http://citeseerx.ist.psu.edu/viewdoc/download?doi=10.1.1.488.9458\&rep=repl\&type=pdf

Mustapha, B. (2017). Effects of Marketing Mix Strategy on Performance of Small Scale Businesses in Maiduguri Metropolitan, Bomo State Nigeria. Journal of Marketing and Consumer Research. 31: 1-6. Accessed from www.iiste.org

Mustapha, B. (2017). Effects of Marketing Mix Strategy on Performance of Small Scale Businesses in Maiduguri Metropolitan, Bomo State Nigeria. Journal of Marketing and Consumer Research. 31(1): 1-6. Retrieved on 23/6/2108 from: www.iiste.org

Njoroge, RM. (2015). Marketing Strategies and the Performance of Small and Medium Enterprises In Matuu Town, Machakos County, Kenya. A Thesis: University of Nairobi

Ogbadu, E.E. (2012). Appraisal Of The Practical Application Of Marketing Research By SMEs Nigeria. Arabian Journal of Business and Management Review. Vol. 2(2): 27-41

Olutunla, G.T. and Obamuyi, T.M. (2008). An empirical analysis of factors associated with the profitability of Small \& medium enterprises in Nigeria. African Journal Business Management. 2(11): 195200.

Owomoyela, S.K, Oyeniyi, K0 and Ola, O.S, (2013).Investigating the impact of marketing mix elements on consumer loyalty: An empirical study on Nigerian Breweries Plc. Interdisciplinary Journal Of Contemporary Research In Business. 4 (11): 485 -496.

Oyedijo, A., Idris, A.A. and Aliu, A.A. (2012). Impact of Marketing Practices on the Performance of Small Business Enterprises: Empirical Evidence from Nigeria. European Journal of Economics, Finance and Administrative Sciences. 2012(46): 130-146. Accessed from http://www.eurojournals.com/EJEFAS.htm

Porter, M.E. (1980). Competitive Strategy: Techniques for Analyzing Industries. New York: The Free Press.

Porter, M.E. (1985). Competitive Advantage: Creating and Sustaining Superior Performance. New York: The Free 
Press, pp. 75-98.

Rothaermel, R.T. (2012). Strategic Management: Concepts and Cases. McGraw-Hill/Irwin, p. 5

Spillan, J. and Parnell, J. (2006). Marketing Resources and Firm Performance among SMEs. European Management Journal. 24 (3): 1-18

Spillan, J. and Parnell, J. (2006). Marketing Resources and Firm Performance among SMEs. European Management Journal, 24(3): 1-18

Varadarajan, P. R., \& Clark, T. (1994). Delineating the Scope of Corporate, Business, and Marketing Strategy. Journal of Business Research, 31(2-3): 93-105.

Von Neumann, J. and Morgenstem, O. (1947). Theory of Games and Economic Behavior. 2nd edition. Princeton University Press, Princeton

Woldie, A., Leighton, P. and Adesua, A. (2008). Factors influencing small and medium enterprises (SMEs): an exploratory study of owner/manager and firm characteristics. Banks and Bank Systems, 3(3): 5-13 